\title{
PENYULUHAN DAN PEMBUATAN MP-ASI LOKAL DENGAN BAHAN DASAR BMC (BAHAN MAKANAN CAMPURAN) UNTUK BALITA PADA KADER POSYANDU DI WILAYAH KERJA PUSKESMAS CIKULUR KABUPATEN LEBAK 2019
}

\author{
Muhammad Ikhsan AMAR ${ }^{1}$, Nanang NASRULLAH ${ }^{2}$ \\ Prodi IImu Gizi, Fakultas IImu Kesehatan, Universitas Pembangunan Nasional Veteran Jakarta \\ Email: ompumbozho90@gmail.com
}

\begin{abstract}
Changes in the need for exclusive breastfeeding to complementary foods generally occur at the age of 6-24 months, and this period is very sensitive to the occurrence of malnutrition in children. Implemented supplementary feeding will help overcome the problem of malnutrition and poor nutrition and support the optimal growth and development of infants and children (MOH RI, 2004). The purpose of this activity is to increase the knowledge and skills of posyandu cadres in making quality and nutrient-dense complementary foodsby utilizing Mixed Food Ingredients (BMC) from local materials, and in the end this knowledge and skills can be disseminated to the community especially mothers of toddlers in Anggalan Village, Cikulur District, Lebak Regency.

Method The activity was held in the form of counseling on the making of complementary foods with Basic Materials of for Toddlers to Posyandu Cadres with counseling methods to increase knowledge about the procedures and patterns of supplementary feeding for toddlers. There were about 40 people from nursing mothers who were present listening to counseling.

The results of the activity showed that there was an increase in mothers' knowledge about how to utilize existing local food materials so that they could be used as complementary foods after counseling about complementary foods with BMC Basic Materials for Toddlers. Seeing the condition of the village, a lot could actually be used or processed into various kinds processed foods including complementary foods, so people need to be encouraged to empower these resources.
\end{abstract}

Keywords: Complementary Foods, BMC, Counseling

\section{ABSTRAK}

Perubahan kebutuhan dari ASI eksklusifkemakanan pendamping umumnya terjadi pada usia 624 bulan, dan periode ini sangat sensitif untuk terjadinya malnutrisi pada anak. Dilaksanakan pemberian makanan tambahan dalam bentuk MP-ASI akan membantu mengatasi masalah gizi kurang dan buruk serta menunjang tumbuh kembang bayi dan anak secara optimal (Depkes RI,2004). Tujuan kegiatan pengabdian masyarakat ini adalah meningkatkan pengetahuan dan ketrampilan kader posyandu dalam pembuata MP-ASI yang berkualitas dan padat gizi dengan memanfaatkan Bahan Makanan Campuran (BMC) dari bahan lokal, dan pada akhirnya pengetahuan dan ketrampilan ini dapat disebarluaskan kepada masyarakat terutama ibu-ibu balita di Desa Anggalan Kecematan Cikulur Kabupaten Lebak.

Metode Kegiatan yang diadakan berupa penyuluhan pembuatan MP-ASI dengan Bahan Dasar BMC untuk Balita pada Kader Posyandu dengan metode penyuluhan untuk meningkatkan 
pengetahuan mengenai tata cara dan pola pemberian makan tambahan bagi balita. Waktunya pelaksanaanya itu hari Jumat, 20 September 2019. Berlokasi di Desa Anggalan, Kecamatan Cikulur, Kabupaten Lebak, Banten Peserta kegiatan ini selain Kader Posyandu, melibatkan secara langsung ibu-ibu menyusui di desa tersebut. Ada sekitar 40 orang dari ibu-ibu menyusui yang turut hadir mendengarkan penyuluhan.

Pentingnya diadakannya kegiatanini, adalah memberdayakan potensi sumberdaya lokal yang ada di daerah setempat. Hasil kegiatan menunjukkan terdapat peningkatan pengetahuan ibu tentang bagaimana memanfaatkan bahan pangan lokal yang ada sehingga dapat dimanfaatkan menjadi MPASI setelah dilakukan penyuluhan tentang MP-ASI dengan Bahan Dasar BMC untuk Balita Melihat kondisi desa, banyak sekali sebetulnya yang bisa dimanfaatkan ataupun diolah menjadi berbagai macam makanan olahan termasuk MP-ASI, sehingga masyarakat perlu didorong untuk memberdayakan sumberdaya tersebut.

Kata kunci: MP-ASI, BMC, Peyuluhan, Edukasi

\section{PENDAHULUAN}

Makanan pendamping ASI (MP-ASI) harus diberikan sebagai makanan tambahan diberikan apabila ASI tidak mencukupi nutrisi. Perubahan kebutuhan dari ASI eksklusif ke makanan pendamping umumnya terjadi pada usia 6-24 bulan, dan periode ini sangat sensitif untuk terjadinya malnutrisi pada anak. Menurut WHO (1998), anak sampai umur 6 bulan tetap tumbuh normal dan sehat dengan hanya memberi ASI. Setelah anak berusia 6 bulan MP-ASI harus diberikan karena kebutuhan gizi anak semakin meningkat dan tidak dapat dipenuhihanya dengan ASI. Bentuk MP-ASI yang diberikan juga harus disesuaikan dengan kemampuan pencernaan anak dan mengandung cukup energi, protein serta vitamin dan mineral secara cukup. Sebuah penelitian di Ghana yang dilaksanakan oleh Lastey A.et al (1999) menemukan bahwa pemberian MP-ASI lokal yang diperbaiki formulanya dapat menghasilkan penambahan BB dan PB yang bermakna pada anak 6-12 bulan bila dibandingkan dengan anak yang tidak diberi (Karmini,2008).

Masalah kekurangan konsumsi akan kebutuhan gizi akan berdampak nyata pada timbulnya masalah gizi terutama masalah gizi pada balita. Adapun faktor yang paling berpengaruh terhadap masalah kekurangan gizi pada balita adalah masih minimnya atau rendahnya pengetahuan masyarakat tentang pemeliharaan gizi balita sehingga konsumsi zat gizi anak akan berkurang, berkurangnya komsumsi secara ade kuat zat gizi sehari-hari dapat menyebabkan menurunya daya tahan tubuh terhadap imunitas dan gampang tererang oleh penyakit infeksi, dimana keadaan ini akan semakin memperburuk status gizi pada balita.

Selama ini, praktek pemberian makanan pendamping ASI (MP ASI) pada balita, seringkali tidak diperhatikan terutama dalam hal kepadatan zat gizinya. Hal ini terjadi karena masih rendahnya pengetahuan dan ketrampilan ibu balita dalam hal cara membuat dan menyajikan MP-ASI yang padat gizi. Hasil observasi yang dilakukan bulan Agustus 2018 di Puskesmas Cikulur dan berdasarkan informasi dari kader dan ibu-ibu yang memiliki balita, dijumpai masih banyak ibu balita yang hanya memberikan makanan berupa bubur beras saja tanpa dilengkapi dengan bahan makanan lain yang bergizi, seperti lauk hewani dan sayuran. Terdapat juga ibu balita memberikan makanan kepada balitahanya berupa kuah sayur-sayuran tanpa bahan makanan sumber protein. Di samping itu, ditemui pula adanya pendapat masyarakat bahwa MP-ASI padat gizi hanya dapat dibuat dari bahan makanan sumber hewani, yang harganya relatif mahal.

MP-ASI dapat dibuat dari bahan makanan campuran yang padat gizi, dengan harga relatif terjangkau dan bahan mudah didapatkan. Pembuatannyapun mudah, salah satunya dengan menggunakan bahan makanan campuran lokal seperti kacang-kacangan, sayur-sayuran dan serelia. Pemberian MP-ASI lokal memiliki beberapa dampak positif, antara lain ibu lebih memahami dan lebih 
terampil dalam membuat MP-ASI dari bahan pangan lokal sesuai dengan kebiasaan dan sosial budaya setempat, sehingga ibu dapat melanjutkan pemberian MP-ASI lokal secara mandiri.

Dari berbagai permasalahan di atas, tampaknya masyarakat membutuhkan informasi tentang bagaimana cara membuat dan menyajikan MP-ASI yang berkualitas dan padat gizi. Salah satu bahan makanan yang dapat dimanfaatkan untuk membuat MP-ASI padat gizi adalah BMC (Bahan Makanan Campuran) lokal. Model penjelasan tentang pembuatan MP-ASI dengan bahan dasar BMC kepada ibu balita mungkin akan lebih efektif jika dilakukan oleh kader posyandu. Hal ini disebabkan karena kader merupakan pembawa dan penyampai misi pembangunan kesehatan ditingkat paling bawah yang langsung berhubungan dengan masyarakat.

Tujuan umum dari kegiatan pengabdian masyarakat ini adalah meningkatkan pengetahuan dan ketrampilan kader posyandu dalam pembuata MP-ASI yang berkualitas, padat gizi dan bervolume kecil dengan memanfaatkan Bahan Makanan Campuran (BMC) dari bahan lokal, dan pada akhirnya pengetahuan dan ketrampilan ini dapat disebarluaskan kepada masyarakat terutama ibu-ibu balita.

\section{METODE PELAKSANAAN}

\section{A. Tahapan Kegiatan}

Tahap Persiapan

1. Pada tahap ini, akan dilakukan pemenuhan kebutuhan administrasi dilakukannya program pengabdianlbM serta konsolidasi dengan pihak mitra.

2. Penyuluhan dan pembuatan MP-ASI lokal dengan bahan dasar BMC (bahan makanan campuran).

3. Tahap Pembuatan Instrumen Brosur Pelatihan: Pada tahap ini akan dibuat brosur yang dapat dijadikan acuan dalam pelatihan pembuatan MP-ASI lokal dengan bahan dasar BMC (bahan makanan campuran).

Adapun kriteria inklusi partisipan dalam pengabdian IbM ini antara lain:

1. Merupakan ibu kader Posyandu.

2. Bersedia berpartisipasi dan menjalani seluruh rangkaian program pengabdian IbM.

3. Pelaksanaan penyuluhan dan pelatihan serta pengembangan diversifikasi pangan.

4. Focus Group Discussion (FGD); FGD dilakukan untuk mengetahui kualitas dan hasil dari pembuatan MP-ASI lokal dengan bahan dasar BMC (bahan makanan campuran).

B. Pendekatan Pengabdian Kepada Masyarakat :

1. Pendekatan yang digunakan adalah model penyuluhan

2. Memberikan pelatihan kreatifitas pada kader posyandu yaitu pembuatan MP-ASI lokal dengan bahan dasar BMC (Bahan Makanan Campuran) dalam pemenuhan kebutuhan gizi harian anak balita.

C. Partisipasi Mitra Pengabdian IbM

Bentuk partisipasi mitra pengabdian IbM antara lain:

1. Mengakomodir partisipan yang sesuai dengan kriteria inklusi dan bersedia untuk berpartisipasi pada setiap tahapan pelatihan dan pengembangan pembuatan MP-ASI lokal dengan bahan dasar BMC (bahan makanan campuran).

2. Mengikuti pelatihan dengan saksama dan serius.

3. Memberikan komentar dalam pelaksanaan FGD setelah program pelatihan 


\section{HASIL DAN PEMBAHASAN}

Berlokasi di Desa Anggalan, Kecamatan Cikulur, Kabupaten Lebak, Banten, tim dari Program Studi Gizi, Fakultas Kesehatan Masyarakat melaksanakan kegiatan pengabdian masyarakat. Desa ini dapat ditempuh selama kurang lebih tiga jam dari kampus UPN Veteran Jakarta. Lokasi ini dipilih karena merupakan salah satu daerah binaan LPPM UPN Veteran Jakarta sehingga menjadi daerah utama dalam pelaksanaan kegiatan pengabdian masyarakat. Kegiatan pengabdian masyarakat yang diadakan berupa Penyuluhan dan pelatihan Pembuatan MP-ASI dengan Bahan Dasar BMC (Bahan Makanan Campuran) untuk Balita pada Kader Posyandu. Adapun waktunya pelaksanaan yaitu hari Jumat, tanggal 20 September 2019. Pelaksanaan kegiatan juga bekerjasama dan berkoordinasi dengan Puskesmas Cikulur, Kabupaten Lebak, Banten.

Peserta kegiatan pengabdian kepada masyarakat ini selain Kader Posyandu, melibatkan secara langsung ibu-ibu menyusui di desa tersebut. Ada sekitar 40 orang dari ibu-ibu menyusui yang turut hadir mendengarkan penyuluhan. Kegiatan berlangsung selama kurang lebih dua jam disertai dialog interaktif bersama warga masyarakat khususnya ibu-ibu yang memiliki balita. Tim kegiatan pengabdian masyarakat ini terdiri atas M. Ikhsan Amar, S.Gz, M.Kes (Ketua Tim) dan Nanang Nasrulloh, STP, M.SI. (Anggota)

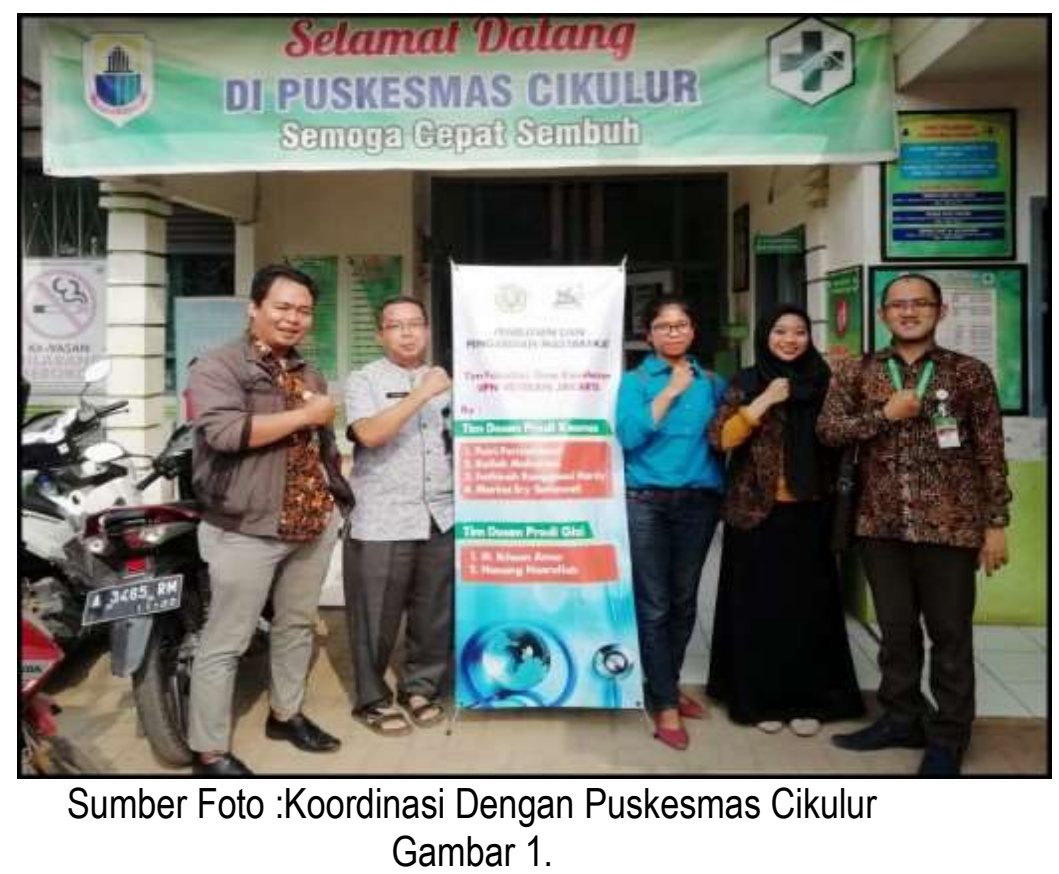

Kegiatan pengabdian kepada masyarakat merupakan kegiatan upaya meningkatkan derajat kesehatan masayarakat, serta memberdayakan potensi sumberdaya lokal yang ada di daerah setempat. MP-ASI merupakan bagian dari upaya kesehatan untuk meningkatkan pertumbuhan balita selama menyusui. Jika hanya ASI saja yang diberikan tanpa adanya MP-ASI maka pertumbuhan serta perkembangan balita menjadi kurang optimal. Oleh karena itu diperlukan pemberian edukasi kepada ibu-ibu menyusui serta kader posyandu dalam mengolah berbagai macam pangan lokal untuk menjadi MP-ASI.

Materi penyuluhan berupa pentingnya MP-ASI bagi pertumbuhan dan perkembangan balita, jenis-jenis MP-ASI dan contoh praktis dari menu MP-ASI. Selain materi tersebut juga diberikan bagaimana memanfaatkan bahan pangan lokal yang ada sehingga dapat dimanfaatkan menjadi MPASI. Melihat kondisi desa, banyak sekali sebetulnya yang bisa dimanfaatkan ataupun diolah menjadi berbagai macam makanan olahan termasuk MP-ASI, sehingga masyarakat perlu didorong untuk memberdayakan sumberdaya tersebut. 
Di samping itu, sebagian besar MP-ASI merupakan BMC. Menurut Damayanti (2003), makanan tambahan dan makanan pendamping ASI dapat dibuat dari bahan makanan campuran yang terdiri dari beberapa bahan makanan dengan perbandingan tertentu sehingga kadar zat gizi dan mutu gizinya menjadi lebih tinggi. Komposisi dan konsistensi MP-ASI disesuaikan dengan umur anak berupa cair dan lunak( semi padat ) untu kanak 4-8 bulan serta padat untuk umur 1-5 tahun. Hal ini sesuai dengan Septimurni (2001) bahwa komposisi dan konsistensi PMT dan MP-ASI harus disesuaikan dengan perkembangan fisiologis \& psikomotorik atau umur anak.

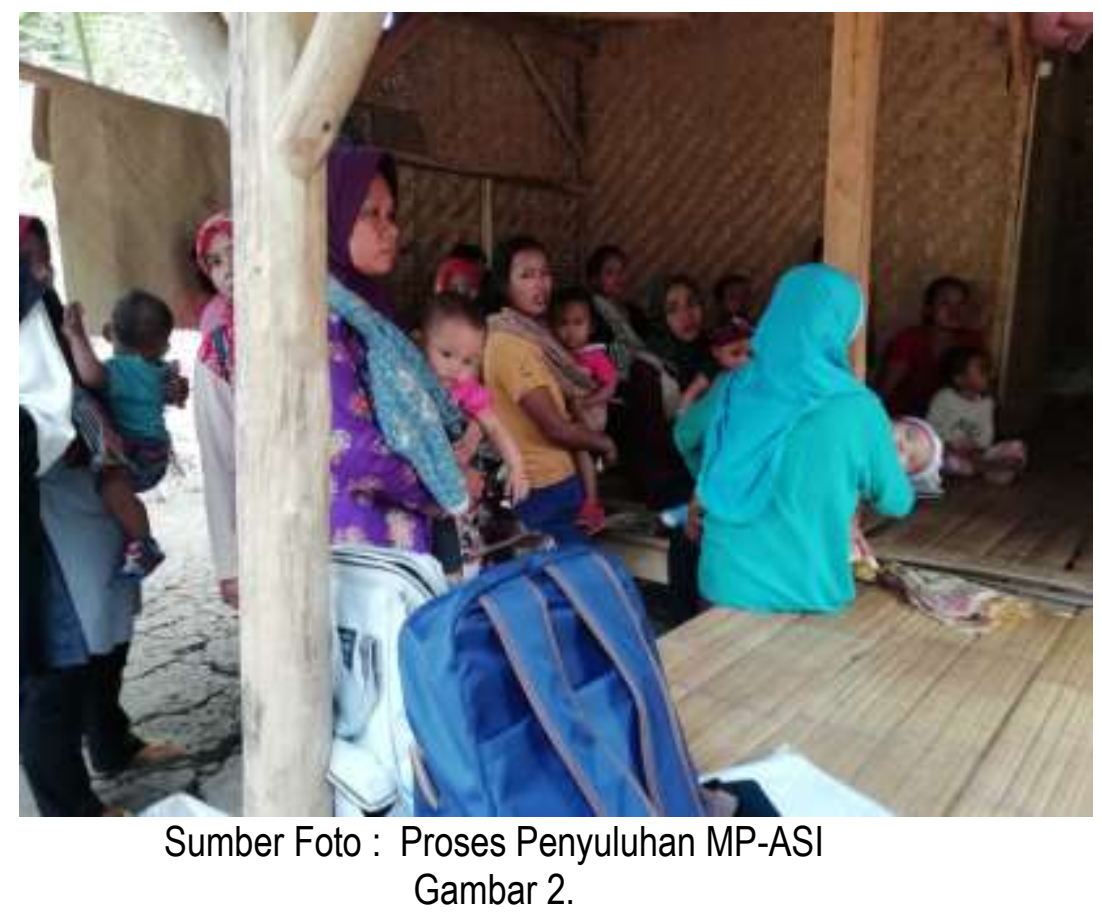

Setelah dialog interaktif dan penyuluhan selama tiga jam, kegiatan pengabdian masyarakat berakhir pada jam 11.30 WIB. Sebelum pulang, tim pengabdian masyarakat berpamitan terlebih dahulu dengan pihak Puskemas Cikulur. Pihak Puskesmas Cikulur mengharapkan adanya kelanjutan kegiatan tersebut agar pengetahuan masyarakat sekitar meningkat khususnya berkaitan dengan pembuatan MP-ASI dengan bahan dasar panganan lokal. Kiranya kegiatan pengabdian kepada masyrakat ini terus berlanjut sehingga tujuan akan tercapai dan harapan paling besar desa Anggalan, Kecamatan Cikulur, Kabupaten Lebak, Banten ini merupakan wujud nyata sebagai lokasi binaan sehingga peningkatan derajatk esehatan.

\section{SIMPULAN}

Setelah diadakan penyuluhan dan pelatihan, dapat disimpulkan bahwa terdapat peningkatan pengetahuan dan ketrampilan kader posyandu serta ibu-ibu yang memiliki balita tentang cara membuat MP-ASI dengan bahan-bahan lokal yang ada di sekitar lingkungan, yang berkualitas terutama dari BMC, dengan skor pengetahuannya sebelum pelatihan 58,11\% (kurang) menjadi 95,74 \% (baik). Di samping itu juga harapan paling besar yaitu, kader posyandu menyebarluaskan pengetahuan dan ketrampilan pembuatan MP-ASI lokal dengan bahan dasar BMC kepada masyarakat di sekitar posyandu. Berdasarkan hasil kegiatan ini, perlu lebih ditingkatkan mutu penyuluhan dan pelatihan baik dari segi waktu dan frekuensi agar kader posyandu dan masyarakat lebih banyak mendapat pengetahuan dan ketrampilan sehingga pengalamannya semakin bertambah dalam pembuatan MPASI lokal. Perlu diintensifkan kegiatan diskusi dan ceramah tentang kesehatan dan gizi dengan memberdayakan bidan dan kader sebagai agent of change. 


\section{UCAPAN TERIMA KASIH}

Pada kesempatan ini kami mengucapkan terima kasih kepada: Ibu Rektor melalui Lembaga Pengabdian Masyarakat Universitas Pembangunan Nasional Veteran Jakarta yang telah memberikan ijin kegiatan ini beserta seluruh staffnya, Bapak Dekan Fakultas IImu Kesehatan UPN Veteran Jakarta yang sangat mendukung dan memberikan kesempatan beserta ijin untuk melaksanakan kegiatan ini, Kepala Puskesmas Cikulur dan staffnya yang telah memberikan ijin tempat dan memberikan dorongan semangat dalam penyelenggaraan kegiatan ini, Ibu-ibu kader posyandu di wilayah kerja Puskesmas atas peran dan partisipasinya dan semua pihak yang telah membantu dalam pelaksanaan kegiatan ini yang tidak dapat kami sebutkan satu persatu.

\section{REFERENSI}

Boer, R. 2017. Food Security Monitoring Bulletin INDONESIA. Bogor: FAO Indonesia.

Damayanti, Yuniar.. 2003. "Pengaruh Jenis Kacang-Kacangan Sebagai Bahan Makanan Campuran (BMC) Dari Bekatul Dan Tepung Kacang- Kacangan Berbentuk Biskuit Ditinjau Dari Kadar Protein Dan DayaTerima". KaryaTulis IImiah. Surakarta: Fakultas IImu Kesehatan - UMS

Khaeron, E. H., Yuyun, Sudarjat \& Sendjaja, T. 2016. Assessment of Sustainable Food Diversification Development Model in West Java, Indonesia. International Journal of Humanities and Social Science 6, 175-181.

Gibson RS. 2005. Principle of Nutrional Assessment. New York. Oxford University Press

Hanani, N. 2009. Food Security. Papers. Workshop on Food Security in East Java.

Hendrayana, R. and Ariani, M. 2013. Food Diversification and Transformation Development. The paradox of success of diversification. Case: West Nusa Tenggara Province. 246-263. Research and Development of the Ministry of Agriculture. IAARD Press. Bogor

Dulmansyah, I. 2002. Availability and Food Consumption of Lampung Population (a Resource Analysis of Food and Nutritional Status of Disadvantaged Regions Population of Lampung During Crisis Years (19951999). Dissertation. Bogor Agricultural Institute. Bogor

Djauhari, A. 2013. Food Diversification and Transformation of Agricultural Development. Structural Analysis of Household Expenditure on Food Consumption Diversification Support. 204-215. Research and Development of the Ministry of Agriculture. IAARD Press. Bogor. 